Article

\title{
Chemical Composition and Concentration of Bioactive Compounds in Garlic Cultivated from Air Bulbils
}

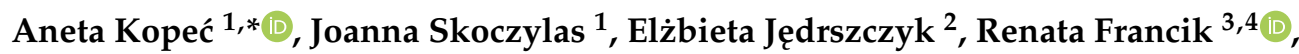 \\ Beata Bystrowska ${ }^{5}$ (D) and Jerzy Zawistowski ${ }^{6}$
}

1 Department of Human Nutrition, Faculty of Food Technology, University of Agriculture in Krakow, Balicka 122, 31-149 Kraków, Poland; joannaskoczylas7@gmail.com

2 Department of Vegetable and Medicinal Plants Faculty of Biotechnology and Horticulture, University of Agriculture in Krakow, al. 29 Listopada 45, 31-425 Kraków, Poland; elzbieta.jedrszczyk@urk.edu.pl

3 Department of Bioorganic Chemistry, Jagiellonian University, Medical College, Pharmacy Faculty, Medyczna 9, 30-688 Kraków, Poland; renata.francik@gmail.com

4 Institute of Health, State Higher Vocational School, Staszica 1, 33-300 Nowy Sacz, Poland

5 Toxicology Department, Faculty of Pharmacy Jagiellonian University Collegium Medicum Medyczna Street 9, 30-688 Krakow, Poland; beata.bystrowska@uj.edu.pl

6 Food, Nutrition and Health, Faculty of Land and Food Systems, University of British Columbia, Vancouver, BC V6T 1Z4, Canada; jzawisto@mail.ubc.ca

* Correspondence: aneta.kopec@urk.edu.pl; Tel.: +48-126624818

Received: 23 December 2019; Accepted: 6 February 2020; Published: 9 February 2020

check for updates

\begin{abstract}
This study was designed to determine the chemical composition, antioxidant activity, and selected bioactive compound content and occurrence in whole immature and mature garlic plants grown from air bulbils. Two winter garlic cultivars, Harnaś and Ornak, of Polish origin, were cultivated from air bulbils at the Experimental Station of the Agricultural University in Kraków, Poland. Harvest bunching of garlic of both cultivars was carried out in May and in June. Mature plants were harvested in July. In whole plant proximate analysis, the concentration of vitamin $\mathrm{C}$, total polyphenols, antioxidant activity, carotenoids, chlorophyll a and b, as well as glutathione level were determined. P-coumaric acid was found in Harnaś and Ornak samples collected in May. Sinapinic acid was identified in Ornak samples collected in June and July. Identification of sulphur compounds depended on the term of harvesting. Significantly higher content of total phenolic compounds, antioxidant activity, as well as other bioactive compounds, was measured in the Harnaś and Ornak cultivars harvested in May. A significantly lower level of bioactive compounds was determined in mature plants harvested in July. The organosulfur compound profile and polyphenolic profile depended on the time of harvesting. Immature garlic cultivated from air bulbils is recognized as a potential source of bioactive compounds in human nutrition, however, more research, in particular in vivo studies, is required to confirm its functional properties.
\end{abstract}

Keywords: air bulbils; garlic; antioxidant activity; polyphenolic compounds; sulphur compounds

\section{Introduction}

Garlic (Allium satioum L.) is one of the world's most important vegetables cultivated for both its culinary and health properties. Garlic cloves are recognized as a valuable source of bioactive compounds for functional foods, natural health products, cosmetics, and medicine for people and animals [1,2]. Garlic is a seasonal vegetable, which loses its beneficial substances during long-term storage [3,4]. It has been reported that the bioactive compounds of the green parts of garlic can provide 
the same health benefits as garlic cloves. The popularity of the green parts of garlic is increasing, especially in Asia [5-9].

Growing garlic from air bulbils is not popular. In many cases it is used only for rejuvenating garlic strains $[8,10]$. However, before harvesting mature plants, it is an alternative way to obtain young plants that are rich in bioactives. Plants obtained from air bulbils are more resistant to various diseases including virus infections. Virus infections of garlic cultivated from cloves affect the size of the cloves and affect the yield of garlic $[10,11]$. Scapes with air bulbils are usually treated as by-products of the garlic plant. The literature contains little information on the composition and antioxidant activities of the by-products of garlic leaves, as well as garlic cultivated from air bulbils $[7,8,12,13]$. On the basis of the above-mentioned information, this study was designed to determine the chemical composition, antioxidant activity, and concentration of selected bioactive compounds in whole young plants of two winter garlic cultivars of Polish origin, Ornak and Harnaś, grown from air bulbils.

\section{Materials and Methods}

\subsection{Plant Material}

Two winter cultivars of Harnaś and Ornak garlic were grown from air bulbils at the Experimental Station of the Agricultural University in Kraków, Poland ( $50^{\circ} 07^{\prime} 910^{\prime \prime} \mathrm{N}, 19^{\circ} 84^{\prime} 764^{\prime \prime}$ E). During the growing season, no chemical protection was applied due to the absence of signs of pests and disease. Fresh samples of whole garlic plants, including bulbs and leaves, were harvested in May, June, and July (mature plants). The plants were thoroughly cleaned. Samples were frozen and, subsequently, freeze-dried in a lyophilizer (Christ Alpha 1-4, Gefriertrocknungsanlagen, Osterode am Harz Germany). Some of the fresh samples were used to prepare methanolic extracts, (70\% methanol was used for extraction) [14] to be analyzed for total polyphenols, antioxidant activity, and other bioactive compounds, as described below. Extract were prepared in duplicate.

\subsection{Proximate Analysis}

The proximate analysis was measured in the freeze-dried samples. Dry matter, total proteins, raw fat, and ash were measured according to the AOAC official methods 32.1.03, 978.04, 935.38, 930.05, respectively [15]. Dry matter was determined in a laboratory oven (Memmert GmbK Schwabach Germany). For nitrogen concentration the Kiejdalh method was used with equipment for digestion and distillation of samples (FOSS Digester and Autodistillation Unit Kjeltec ${ }^{\mathrm{TM}} 8200$, Tecator Foss, Hillerød, Sweden). The factor 6.25 was used to obtain the concentration of protein in samples. The crude fat content was determined by the Soxhlet method using a Soxtec Avanti's 2050 Auto Extraction Unit (Tecator Foss, Hillerød, Sweden). Ash content was measured in the electric muffle furnace (SNOL 82/110, Utena, Lithuania). The total carbohydrate content, in dry matter, was calculated using the following formula: total carbohydrates $=100-($ protein + raw fat + ash $)[14,16]$.

\subsection{Vitamin C, Total Polyphenol Content, and Antioxidant Activity Concentration}

The level of vitamin C (the sum of ascorbic and dehydroascorbic acid) was determined in fresh whole plant samples employing the Tillman method modified by Pijanowski [17]. In the above-mentioned method, dehydroascorbic acid is reduced to ascorbic acid in the presence of sodium sulfide ( $\mathrm{POCH}$, Gliwice, Poland). Mercury chloride ( $\mathrm{POCH}$, Gliwice, Poland) solution was used to precipitate the excess amount of sodium sulfide and 2,6-dichlorophenolindophenol ( $\mathrm{POCH}$, Gliwice, Poland) was used for titration to determinate the sum of ascorbic acid and dehydroascorbic acid in samples of garlic.

To obtain methanolic extracts, one gram of each fresh garlic sample was weighed into an Erlenmeyer flask and then $80 \mathrm{~mL}$ of the $70 \%$ methanol (POCH, Gliwice Poland) was added. The samples were extracted at room temperature in in laboratory shaker without light (Elpan, water bath shaker type 357, Lubawa, Poland) for $2 \mathrm{~h}$. Next, samples were centrifuged at $1500 \mathrm{rpm}$ for $15 \mathrm{~min}$ (Centrifuge type 
MPW-340, Warsaw, Poland). Obtained extracts were stored at $-20^{\circ} \mathrm{C}$ until future analysis, as was previously reported [14].

The total polyphenol content in methanolic extracts was determined using Folin-Ciocalteu reagent (Sigma-Aldrich, Saint Louis, MO, USA) [18]. Methanolic extracts were diluted to receive the ratio of extracts to distilled water 1:20. Then, the diluted extracts were mixed with Folin-Ciocalteu reagent and $25 \%$ sodium carbonate (POCH, Gliwice, Poland). The obtained samples were left in the dark for $20 \mathrm{~min}$ and absorbance was measured at $760 \mathrm{~nm}$ with a spectrophotometer (UV-1800, RayLeigh, Beijing Beifen-Ruili Analytical Instrument Co., Ltd., Beijing, China). The results were shown as the chlorogenic acid equivalent (CGA) in mg per $100 \mathrm{~g}$ fresh sample.

The antioxidant activity of methanolic extracts of garlic samples was determined using the following methods: ABTS $^{\bullet+}\left(2.2^{\prime}\right.$-Azino-bis (3-ethylbenzthiazoline-6-sulfonic acid)), FRAP (ferric-reducing antioxidant power), as well as DPPH. The determination of antioxidant activity using $\mathrm{ABTS}^{\bullet+}$ free radicals was measured using a method described by Re et al. [19]. The FRAP assay was performed according to Benzie and Strain [20]. Determination of antioxidant activity with the DPPH method was performed in accordance to Miliauskas et al. [21].

The results obtained for each sample using the $\mathrm{ABTS}^{\bullet+}, \mathrm{FRAP}$, and DPPH methods were compared to the concentration-response curve of the standard Trolox solution and presented as micromoles of Trolox equivalent per gram of dry weight (TEAC) of samples.

\subsection{Determination of Carotenoids, Chlorophyll $a$ and $b$}

Carotenoids and chlorophyll $\mathrm{a}$ and $\mathrm{b}$ concentration were measured according to Lichtenthaler and Wellburn [22]. From every cultivar, 20 fresh whole plans and in the case of chlorophyll, leaves were taken to obtain an average sample. A $0.1 \mathrm{~g}$ sample was weighted on an analytical scale (Radwag, Krakow, Poland) and ground with sand and magnesium carbonate (POCH Gliwice, Poland) in a mortar. The extraction of carotenoids and chlorophyll a and b was carried out with $25 \mathrm{~mL} 80 \%$ acetone (POCH Gliwice, Poland). The solution was transferred into a centrifuge tube, covered with aluminium foil, and set aside in the dark for $0.5 \mathrm{~h}$ and, then, centrifuged for $10 \mathrm{~min}$ in a MPW-351 RH centrifuge, (Warsaw, Poland). The absorbance of the resulting extracts was measured at wavelengths of $470 \mathrm{~nm}, 646$ $\mathrm{nm}$, and $663 \mathrm{~nm}$, using the Helios Beta UVB1002 E spectrophotometer (Thermo Electron Corporation, Paisley, UK).

\subsection{Determination of Glutathione}

The reduced form of glutathione (GSH) was measured according to the Guri method with a slight modification [23]. From each object, three samples for extraction were taken. Glutathione was extracted from $3 \mathrm{~g}$ of plants with a $6 \mathrm{~mL}$ of mixture of ethylenediaminetetraacetic acid and trichloroacetic acid (EDTA-TCA, POCH, Gliwice, Poland) (0.18612 g/L EDTA were taken in 3\% TCA). The solution was adjusted to $\mathrm{pH} 7.0$ using a K-phosphate buffer (POCH, Gliwice, Poland). The solution was poured into a centrifuge tube and centrifuged for $10 \mathrm{~min}$ in an MPW-351 RH centrifuge, Warsaw, Poland. The reduced glutathione content was spectrophotometrically determined using Ellman reagent (5.5-dithio-bis-2-nitrobenzoic acid (DTNB), POCH, Gliwice, Poland) with a Helios Beta UVB1002 E spectrophotometer (Thermo Electron Corporation, Paisley, UK). Absorbance of the solution was measured at the wavelength of $412 \mathrm{~nm}$. Glutathione content was calculated using a calibration curve.

\subsection{High-Performance Liquid Chromatography with Diode-Array Detection (DAD) and Tandem Mass} Spectrometry MS/MS Analysis of the Phenolic and Organosulfur Compoud Profile

Acidified methanolic extracts of samples were used for HPLC DAD MS/MS analyses. One gram of sample was weighed into an Erlenmeyer flask and $40 \mathrm{~mL}$ of $0.08 \mathrm{~N}$ hydrochloric acid in $80 \%$ methanol ( $\mathrm{POCH}$, Gliwice, Poland) was added. The mixtures were extracted at room temperature for $2 \mathrm{~h}$ by shaking (Elpan, water bath shaker type 357, Lubawa, Poland). Then, the samples were centrifuged at $1500 \mathrm{rpm}$ for $15 \mathrm{~min}$ (Centrifuge type MPW-340, Warsaw, Poland). The supernatants 
were decanted and stored at $-20{ }^{\circ} \mathrm{C}$ until analysis. All the solvents and standards were of analytical grade. Standards of 3,5-di-caffeoylquinic acid (3,5-diCQA), 3,5-dimethoxy-4-hydroxycinnamic acid (sinapinic acid), p-coumaric acid, ferulic acid, isorhamnetin, quercetin, ruthin, catechin-2.3.4- ${ }^{13} \mathrm{C}_{3}$, and S-allyl-L-cysteine sulfoxide were obtained from Sigma-Aldrich (St. Louis, MO, USA), acetonitrile and chloroform from Merck (Darmstadt, Germany), methanol and formic acid from POCh (Gliwice, Poland). All the stock solutions of standards were prepared in methanol. All the stock solutions were stored at $-20^{\circ} \mathrm{C}$. Further dilutions were done using methanol.

For the analysis of sulfuric compounds, the HPLC method with the DAD detector described by Wallock-Richards et al. [24] was employed with some modifications. The elution conditions were the following: isocratic elution with methanol/water $(80: 20, v / v)$ at $1 \mathrm{~mL} / \mathrm{min}$ with UV detection at $240 \mathrm{~nm}$, $25^{\circ} \mathrm{C}$, total analysis time amounted to $20 \mathrm{~min}$. An injection volume of $10 \mu \mathrm{L}$ was used for all samples. The designation of the phenolic fraction was performed using the Van Hung and Morita [25] method. The Agilent 1100 LC system (Agilent, Waldbronn, Germany), equipped with a degasser, binary pump, auto-sampler, and thermo-stated column compartment in a $20{ }^{\circ} \mathrm{C}$ Thermo Scientific BDS HYPERSIL C18 column $(100 \times 3 \mathrm{~mm}$ I.D., $3 \mu \mathrm{m})$ were employed in chromatographic separation. The choice of apportionment conditions was carried out according to Verardo et al. [26] with some modifications [13]. For the MS/MS analysis the Applied Biosystems MDS Sciex (Concord, ON, Canada) API 2000 triple quadrupole mass spectrometer was used, equipped with an electrospray ionization (ESI) interface.

ESI ionization was carried out in negative ionization mode, with parameters as follows: ion spray voltage (IS) $-4400 \mathrm{~V}$, nebuliser gas $30 \mathrm{psi}$, turbo gas $10 \mathrm{psi}$, temperature of the heated nebuliser $250{ }^{\circ} \mathrm{C}$, and curtain gas 30 psi. Nitrogen (99.9\%) from Peak NM20ZA was used as the curtain and collision gas. The following ion path parameters were used for the compounds analyzed: declustering potential (DP) $20 \mathrm{~V}$, focusing potential (FP) $200 \mathrm{~V}$, entrance potential (EP) $10 \mathrm{~V}$, collision cell entrance potential (CEP) $0 \mathrm{~V}$, and collision cell exit potential (CXP) $2 \mathrm{~V}$, respectively.

\subsection{Statistical Analysis}

All analyses were carried out in triplicate. Results were expressed as the means \pm S.D. Differences between samples were analyzed using the Statistica software v. 10.0 (Tulsa, OK, USA). Duncan's multiple range test was used for testing these differences. $p$-values of $<0.05$ were regarded as significant.

\section{Results and Discussion}

\subsection{Proximate Analysis}

Limited information is available regarding the analysis of whole plant of garlic cultivated from air bulbils. To the best of our knowledge the only similar type of research was conducted by Dyduch and Najda [8], who reported the concentration of dry matter, total carbohydrates, and selected bioactive compounds in leaves and steams of garlic cultivated from air bulbils. Literature data is also available on the chemical composition of fresh scapes, immature whole garlic plants, and garlic leaves $[5,8,12]$ but not garlic cultivated from air bulbils.

In this study, it was found that dry matter, as well as total carbohydrate level, increased with the maturity of the growing plants and the highest concentration was measured in samples collected in July (Table 1). Dyduch and Najda [8] reported a dry matter of between $15.42 \%$ and $17.93 \%$ but in the stems and leaves of immature, winter, Polish garlic cultivated from air bulbils harvested in May, as well as in July. These authors have shown that the concentration of total carbohydrates for the leaves and stems ranged between 18.82 and $21.52 \mathrm{~g} / 100 \mathrm{FM}$. The dry matter in our garlic cultivars more than doubled during the three month growing season and, in July, both cultivars contained twice the amount of than that reported by Dyduch and Najda [8] in immature leaves of winter varieties. 
Table 1. Proximate analysis of whole plants of garlic grown from air bulbils.

\begin{tabular}{|c|c|c|c|c|c|}
\hline $\begin{array}{c}\text { Variety/Time } \\
\text { of Harvest }\end{array}$ & $\begin{array}{c}\text { Dry Matter } \\
\left(\mathrm{g} / 100 \text { g FM }^{\#}\right)\end{array}$ & $\begin{array}{l}\text { Proteins * } \\
\text { (g/100 DM) }\end{array}$ & $\begin{array}{l}\text { Crude Fat* } \\
\text { (g/100 gDM) }\end{array}$ & $\begin{array}{c}\text { Total Carbohydrates * } \\
\text { (g/100g DM) }\end{array}$ & $\begin{array}{c}\text { Ash * } \\
\text { g/100g DM }\end{array}$ \\
\hline $\mathrm{MHa}$ & $16.32 \pm 0.54^{a}$ & $15.07 \pm 0.28^{\mathrm{d}}$ & $3.30 \pm 0.15^{c}$ & $75.52 \pm 0.03^{a}$ & $6.11 \pm 0.10^{d}$ \\
\hline M Ornak ** & $18.36 \pm 0.45^{b}$ & $14.17 \pm 0.41^{\mathrm{c}}$ & $2.74 \pm 0.36^{b c}$ & $76.00 \pm 0.24^{a}$ & $7.09 \pm 0.19^{\mathrm{e}}$ \\
\hline JN Harnaś ** & $28.71 \pm 1.23^{c}$ & $7.65 \pm 0.51^{\mathrm{ab}}$ & $3.06 \pm 0.47^{c}$ & $85.05 \pm 0.82^{c}$ & $4.24 \pm 0.16^{\mathrm{c}}$ \\
\hline JN Ornak ** & $32.28 \pm 0.25^{d}$ & $7.07 \pm 0.04^{a}$ & $6.66 \pm 0.70^{d}$ & $82.22 \pm 1.65^{b}$ & $4.05 \pm 0.02^{c}$ \\
\hline JL Harnaś ** & $35.10 \pm 0.75^{\mathrm{e}}$ & $8.28 \pm 0.12^{b}$ & $1.04 \pm 0.07^{\mathrm{ab}}$ & $87.56 \pm 0.17^{d}$ & $3.07 \pm 0.02^{a}$ \\
\hline JL Ornak ** & $41.41 \pm 0.12^{f}$ & $7.78 \pm 0.44^{\mathrm{ab}}$ & $0.82 \pm 0.02^{\mathrm{a}}$ & $87.95 \pm 0.62^{d}$ & $3.45 \pm 0.45^{b}$ \\
\hline
\end{tabular}

\# g/100 g fresh mass; * g/100 g DM dry matter; ** M Harnaś whole plants harvested in May; ** M Ornak whole plants harvested in May; ** JN Harnaś whole plants harvested in June; ** JN Ornak whole plants harvested in June; ${ }^{* *} \mathrm{JL}$ Harnaś whole plants harvested in July; ${ }^{* *}$ JL Ornak whole plants harvested in July. Values in columns with different letters $\left({ }^{\mathrm{a}}, \mathrm{b}, \mathrm{c}\right)$ are significantly different, $p \leq 0.05$.

Even more significant differences were presented in the level of total carbohydrates. The July samples of both cultivars contained a level four times higher than those reported in the literature (Table 1). Piatkowska et al. [13] showed that, in the mature winter leaves of Polish garlic cultivars, such as Harnaś and Ornak, harvested in July, dry matter concentration amounted to 11.89 and $13.25 \mathrm{~g} / 100$ FM. The level of total carbohydrates in the leaves of same cultivars was 79.6 and $89.0 \mathrm{~g} / 100 \mathrm{~g}$ FM (66.94 and $67.17 \mathrm{~g} / 100 \mathrm{~g} \mathrm{DM})$.

Protein and ash content decreased during plant maturation. Protein concentration in garlic grown from air bulbils, in our study, was significantly lower than in the mature garlic leaves of Harnaś and Ornak cultivars [13]. Furthermore, the same authors have reported four times higher concentration of ash in the garlic leaves of Harnaś and Ornak (14.1 and $13.1 \mathrm{~g} / 100 \mathrm{~g}$ DM, respectively) harvested in July than in our samples of these cultivars harvested during the same month [13].

\subsection{Selected Bioactive Compounds Concentration}

The level of bioactive compounds in whole garlic cultivated from air bulbils decreased significantly during the maturation of the plants. Cultivar Ornak harvested in May and June had the highest concentration of vitamin $C$. The vitamin $C$ level dropped significantly in both cultivars harvested in July (Table 2). It was a higher level than that reported by Dyduch and Najda [8] in garlic leaves grown from the air bulbils harvested in May and June. Piatkowska et al. [13] reported a significantly higher concentration of vitamin $C$ in mature garlic cultivar Harnaś and Ornak leaves (45.97 and 9.88 mg/100 g FM, respectively). Vitamin C in Italian garlic cloves ranged between 11.01 and $21.59 \mathrm{mg} / 100 \mathrm{~g}$ FM [27].

Total polyphenol concentration and antioxidant activity were significantly higher in the Harnas and Ornak cultivars harvested in May as compared with samples harvested in other months (Table 2). This is in line with the lower level of polyphenolic compounds in mature leaves of Harnaś and Ornak cultivars reported by Piątkowska et al. [13]. Chen et al. [9] reported a much higher concentration of polyphenolic compounds and antioxidant activity measured with the DPPH method (12.64 to $22.66 \mathrm{mg} / 1 \mathrm{~g}$ gallic acid, 9.92 to $40.41 \mu \mathrm{mol}$ Trolox $/ \mathrm{g}$ ) in garlic bolts and cloves from cultivars of Chinese origin (17.16 to $42.53 \mathrm{mg} / 1 \mathrm{~g}$ gallic acid, 4.30 to $32.02 \mu \mathrm{mol}$ Trolox/g). Gorinstein et al. [28] also reported a higher possibility of scavenging free radicals assessed with ABTS, FRAP, and DPPH methods, in Polish origin garlic. Piatkowska et al. [13] reported that the antioxidant activity in mature leaves of various Polish, winter cultivars measured by ABTS method was in the range 2.69 to $2.92 \mu \mathrm{mol}$ Trolox/1 g, which was lower as compared with data obtained in our study. 
Table 2. Bioactive compounds content in whole plants of garlic cultivated from air bulbils (g/100 g FM \#).

\begin{tabular}{|c|c|c|c|c|c|c|c|c|c|}
\hline $\begin{array}{c}\text { Variety/Time } \\
\text { of Harvest }\end{array}$ & $\begin{array}{c}\text { Vitamin C } \\
(\mathrm{mg} / \mathbf{1 0 0 g} \mathrm{FM})\end{array}$ & $\begin{array}{c}\text { Total } \\
\text { Polyphenols } \\
\text { (mg/100g FM) }\end{array}$ & $\begin{array}{c}\text { ABTS } \\
(\mu \mathrm{mol} \\
\text { Trolox/g FM) }\end{array}$ & $\begin{array}{c}\text { FRAP } \\
(\mu \mathrm{mol} \\
\text { Trolox/g FM })\end{array}$ & $\begin{array}{c}\text { DPPH } \\
(\mu \mathrm{mol} \\
\text { Trolox/g FM) }\end{array}$ & $\begin{array}{l}\text { Carotenoids } \\
\text { (mg/100g FM) }\end{array}$ & $\begin{array}{c}\text { Chlorophyll } \\
\text { A } \\
\text { (mg/1gFM) }\end{array}$ & $\begin{array}{c}\text { Chlorophyll } \\
\text { B } \\
\text { (mg/1g FM) }\end{array}$ & $\begin{array}{c}\text { Gluthathion } \\
\text { (mg/1gFM) }\end{array}$ \\
\hline M Harnaś * & $27.26 \pm 2.94^{\mathrm{e}}$ & $257 \pm 7^{c}$ & $10.41 \pm 0.07^{\mathrm{e}}$ & $12.21 \pm 0.13^{d}$ & $2.75 \pm 0.01^{b}$ & $0.21 \pm 0.01^{b}$ & $0.61 \pm 0.13^{c}$ & $0.22 \pm 0.01^{d}$ & $20.18 \pm 2.94^{b}$ \\
\hline M Ornak* & $31.51 \pm 0.45^{c}$ & $262 \pm 1^{c}$ & $10.17 \pm 0.03^{\mathrm{e}}$ & $14.37 \pm 0.06^{\mathrm{f}}$ & $2.50 \pm 0.01^{\mathrm{ab}}$ & $0.25 \pm 0.0^{\mathrm{c}}$ & $0.76 \pm 0.07^{\mathrm{d}}$ & $0.23 \pm 0.02^{\mathrm{d}}$ & $16.19 \pm 0.63^{a}$ \\
\hline JN Harnaś * & $23.51 \pm 0.34^{b}$ & $179 \pm 11^{b}$ & $7.85 \pm 0.22^{c}$ & $11.29 \pm 0.10^{c}$ & $2.00 \pm 0.04^{\mathrm{a}}$ & $0.21 \pm 0.01^{b}$ & $0.61 \pm 0.04^{\mathrm{c}}$ & $0.15 \pm 0.01^{\mathrm{c}}$ & $21.99 \pm 1.59^{b}$ \\
\hline JN Ornak* & $28.64 \pm 0.68^{d}$ & $185 \pm 3^{b}$ & $8.87 \pm 0.02^{\mathrm{d}}$ & $13.74 \pm 0.11^{\mathrm{e}}$ & $2.81 \pm 0.01^{b}$ & $0.16 \pm 0.00^{a}$ & $0.50 \pm 0.02^{\mathrm{c}}$ & $0.16 \pm 0.02^{\mathrm{c}}$ & $15.00 \pm 1.73^{a}$ \\
\hline JL Harnaś * & $5.14 \pm 0.45^{\mathrm{a}}$ & $110 \pm 6^{a}$ & $6.65 \pm 0.10^{\mathrm{a}}$ & $6.42 \pm 0.15^{a}$ & $1.98 \pm 0.05^{\mathrm{a}}$ & $0.15 \pm 0.01^{a}$ & $0.34 \pm 0.01^{b}$ & $0.10 \pm 0.00^{b}$ & $13.87 \pm 1.33^{a}$ \\
\hline JL Ornak * & $4.44 \pm 0.30^{\mathrm{a}}$ & $116 \pm 3^{a}$ & $7.52 \pm 0.2^{b}$ & $7.01 \pm 0.06^{b}$ & $2.31 \pm 0.01^{\mathrm{ab}}$ & $0.14 \pm 0.01^{a}$ & $0.19 \pm 0.02^{\mathrm{a}}$ & $0.04 \pm 0.01^{\mathrm{a}}$ & $13.36 \pm 0.67^{a}$ \\
\hline
\end{tabular}

" FM fresh mass; * M Harnaś whole plants harvested in May; * M Ornak whole plants harvested in May; * JN Harnaś whole plants harvested in June; * JN Ornak whole plants harvested in June; * JL Harnaś whole plants harvested in July; ${ }^{*}$ JL Ornak whole plants harvested in July. Values in columns with different letters $\left({ }^{\mathrm{a}}, \mathrm{b}, \mathrm{c}\right)$ are significantly different, $p \leq 0.05$. 
Carotenoids concentration in garlic cultivated from air bulbils ranged between 0.14 and $0.25 \mathrm{mg} / 100 \mathrm{~g}$ FM. For example, garlic cloves of Italian origin contained between 5.68 and 7.46 $\mu \mathrm{g} / 100 \mathrm{~g}$ of $\beta$-carotene [26]. The time of harvesting also affected chlorophyll a and $\mathrm{b}$ content. Similar findings were reported by Dyduch and Najda [8], who found that the level of the aforementioned compounds decreased during the maturation process, in the stems and leaves of garlic cultivated from air bulbils.

Glutathione concentration was significantly higher in whole plants of Harnaś variety harvested in May and June as compared with the Ornak variety collected in the same time, as well, in July. Higher concentration of glutathione in mature leaves of wild garlic (Allium ursinum L., $48.36 \mu \mathrm{g} / 1 \mathrm{~g}$ FM was reported by Jędrszczyk et al. [29].

The analysis of methanolic extracts from Harnaś and Ornak samples harvested during the three month period presented sinapinic acid, p-coumaric acid, and isorahamnetin (Figure 1, Figure 2a,b and Figure $3 a, b)$. Sinapinic acid was detected in the Ornak samples harvested in June and July. P-coumaric acid was identified in the May samples of Harnaś and Ornak. Isorhamnetin was identified in the Ornak samples collected in July (Table 3). It has been reported that the types of phenolic compounds varied from country to country and were dependent on cultivation practices $[29,30]$. White garlic and Chinese cultivars contained higher concentrations of phenolics than purple garlic cultivars [30]. It has also been suggested that it is the country of origin, not changes in garlic genotype, that significantly affects the contents of caffeic, vanillic, p-hydroxybenzoic, and p-coumaric acids. It was explained that environmental conditions and soil type can also affect the polyphenolic content and profile $[28,30]$. Alarcón-Flores et al. [31] reported that the major phenolic compounds identified in Spanish garlic were quercetin, caffeic, and ferulic acid [31]. The same phenolic acids, as in our study, were identified by Gorinstein et al. [28] in cloves of Polish garlic cultivars. Additionally, these authors identified caffeic, vanillic, p-hydroxybenzoic, protocatechuics, and ferulic acids. In garlic husk, some phenolic compounds which were mainly acids were also recognized, i.e., caffeic, hydroxybenzoic, ferulic, p-coumaric, and chlorogenic acids [12]. Mercy et al. [32] showed that the major phenolic compounds in garlic oil from Nigerian garlic were caffeic and ferulic acids.<smiles>COc1cc(/C=C\C(=O)O)cc(OC)c1O</smiles>

sinapinic acid<smiles>C=CCSCC(N)C(=O)O</smiles>

S-allyl-L-cysteine
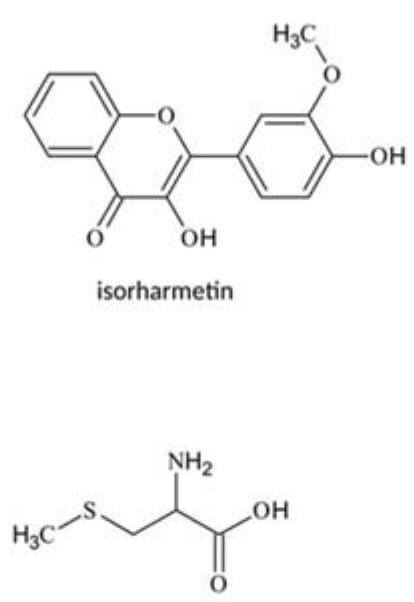

S-methyl-L-cysteine

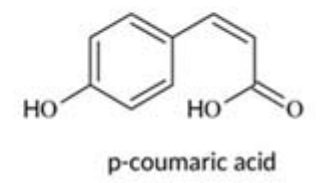<smiles>CC1CS(=O)CC(C(=O)O)N1</smiles>

Cycloalliin

Figure 1. Structures of reference substances used for identification. 




- $\operatorname{MPM}(10$ pairs): 9101 to 10,168 min



Figure 2. (a) Example of a XIC chromatogram obtained for a sample of Ornak collected in May. The chromatogram was obtained for the pair of ions $\mathrm{m} / \mathrm{z}=314 / 300$, identified as isorhamnetin; (b) Fragmentation mass spectrum (MS/MS for $m / z=314-$ isorhamnetin). 

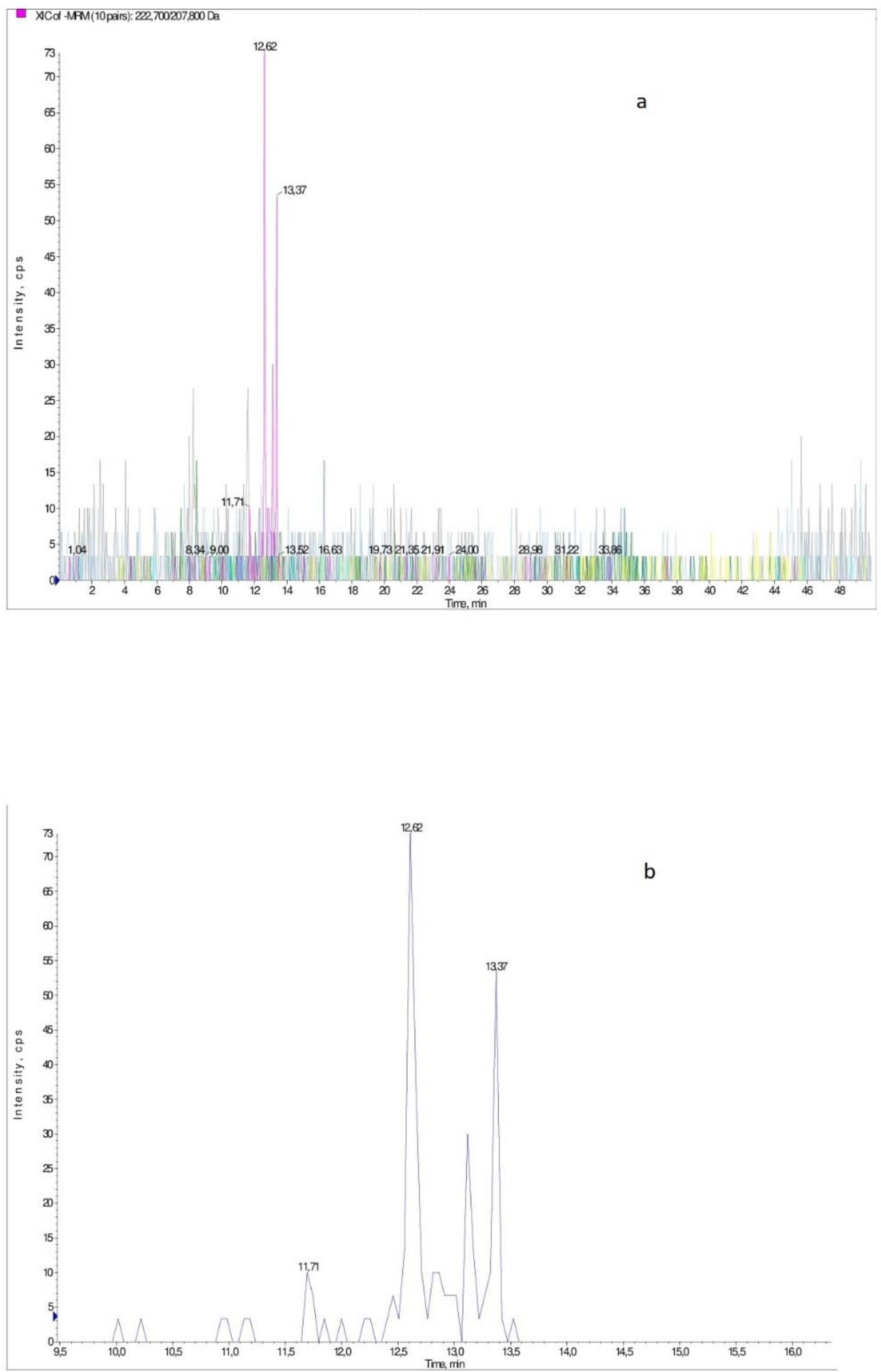

Figure 3. (a) The XIC chromatogram for all ionic pairs of Ornak collected in June; (b). Example of a XIC chromatogram obtained for sample of Ornak collected in June. The chromatogram was obtained for the ionic pair $m / z=222.7 / 207.8$ which was identified as sinapinic acid. 
Table 3. Mass spectrometry parameters for phenolic compounds identified in whole plants of garlic cultivated from air bulbils.

\begin{tabular}{|c|c|c|c|c|c|c|c|c|c|}
\hline Compound & $\begin{array}{c}\text { Molecular } \\
\text { Mass (g/mol) } \\
\text { (M) }\end{array}$ & $\begin{array}{c}m / z \\
\left(\mathbf{M}-\mathbf{H}^{+}\right)^{-}\end{array}$ & $\begin{array}{l}\text { Retention } \\
\text { MRM *- }\end{array}$ & ne (min) & $\mathrm{DP} * *$ & $\mathbf{F P} * * *$ & $\mathrm{CE}^{\#}$ & CXP \#\# & Cultivar \\
\hline Sinapinic acid & 224.21 & 222.70 & 207.80 & 12.88 & -31 & -160 & -12 & -15 & $\begin{array}{l}\text { JL Ornak * } \\
\text { JN Ornak * }\end{array}$ \\
\hline p-Coumaric acid & 164.16 & 162.80 & 119.10 & 19.81 & -31 & -320 & -9 & -22 & $\begin{array}{l}\text { M Harnaś * } \\
\text { M Ornak * }\end{array}$ \\
\hline Isorhamnetin & 316.26 & 314.70 & 300.00 & 24.8 & -91 & -340 & - & -10 & JL Ornak * \\
\hline
\end{tabular}

* Multiple reaction monitoring (MRM); ${ }^{* *}$ DP decluttering potential; ${ }^{* * *}$ FP focusing potential; ${ }^{\#} \mathrm{CE}$ collision energy; ${ }^{\# \prime}$ CXP collision cell exit potential; M Harnaś ${ }^{*}$ whole plants harvested in May; M Ornak* whole plants harvested in May; JN Harnas** whole plants harvested in June; JN Ornak* whole plants harvested in June; JL Harnaś ${ }^{*}$ whole plants harvested in July; JL* Ornak whole plants harvested in July. 
The young plants of garlic cultivated from air bulbils can be a source of sulphur compounds. Furthermore, analyzing the mass spectra of individual extracts based on ion fragmentation and retention times revealed the presence of organosulfur compounds (Table 4). Organosulfur compounds such as $S$-methyl-L-cysteine, S-allyl-L-cysteine, and cycloalliin were identified in the Harnaś samples collected in May. The same cultivar, collected in June, contained S-(trans-1-propenyl)-L-cysteine, S-allyl-L-cysteine sulfoxide (Figure 4), and cycloalliin, while samples harvested in July, contained S-(trans-1-propenyl)-L-cysteine and S-allyl-L-cysteine sulfoxide (Figure 2). Cycloalliin was also present in the Ornak samples collected in June, while $S$-(trans-1-propenyl)-L-cysteine was found in the July samples. These types of compounds have been identified in the Allium genus, such as garlic, onion, and Chinese chive [33]. Although they play an important role in plant defence [32], they are also significant functional components in the reduction of risk or even prevention of chronic illnesses, i.e., cardiovascular diseases, certain types of cancers, and others [31]. It has been suggested that the organosulfur compound profile in garlic cloves was dependent on the time of harvesting, growing conditions, and maturity of garlic [34,35]. Arzanlou and Bohlooli [5] reported that not only mature cloves but also young bulbs, shoots, and leaves can be sources of organosulfur compounds. It is also worth noting that garlic storage, processing, i.e., blanching and fermentation, can affect the profile and level of these compounds $[4,34,35]$.

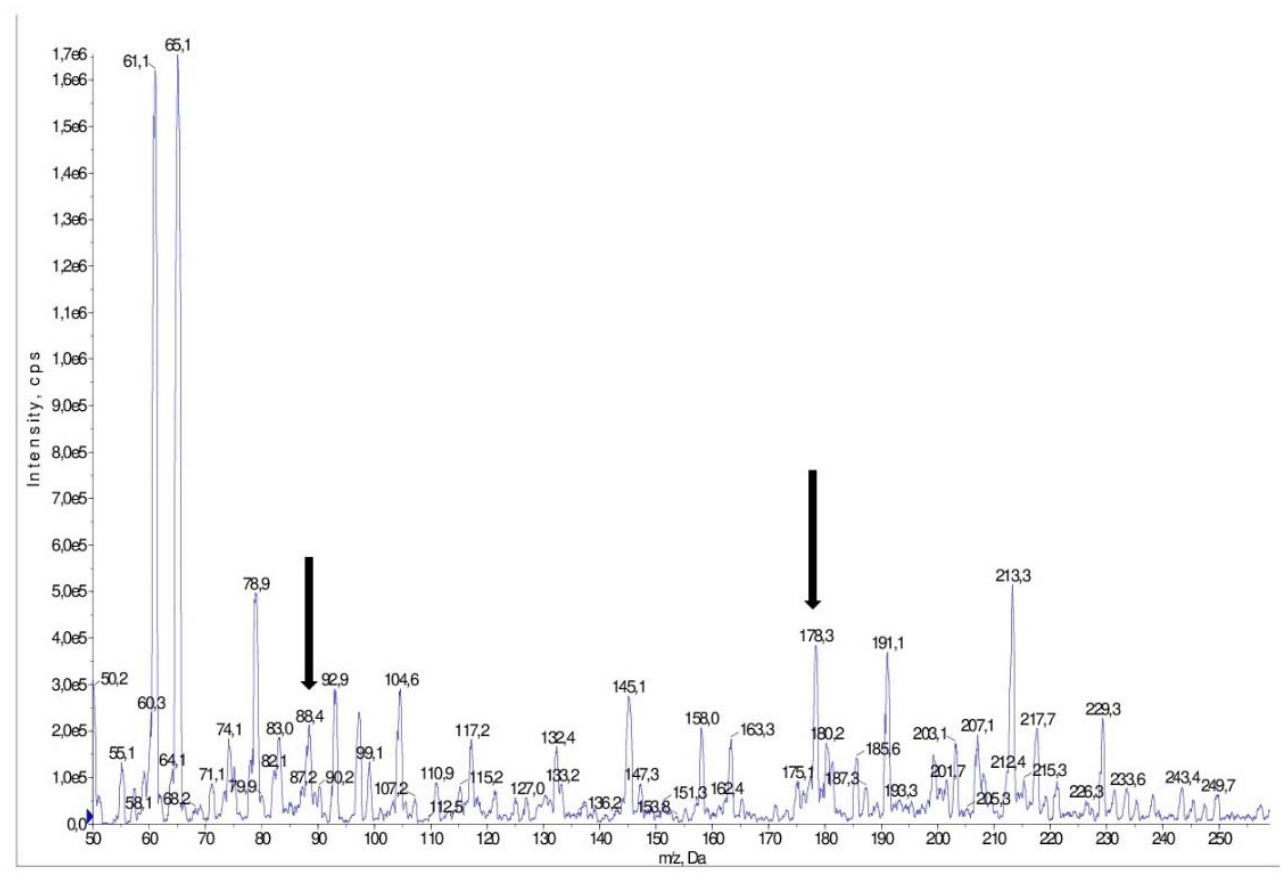

Figure 4. Mass spectrum of a pick obtained for a sample of Harnaś collected in June. The pick was obtained for $S$-allyl-L-cysteine sulfoxide $(m / z=178 / 88)$. The ion pairs, which was identified as $S$-allyl-L-cysteine sulfoxid, is marked with arrows. 
Table 4. Mass spectrometry parameters for organosulfur compounds identified in whole plants of garlic cultivated from air bulbils.

\begin{tabular}{|c|c|c|c|c|c|c|c|c|}
\hline Organosulfur Compounds & $\begin{array}{l}\text { Retention Time } \\
\text { (min) }\end{array}$ & $\begin{array}{c}\text { Precursor Ion } \\
(m / z)\end{array}$ & $\begin{array}{l}\text { Specific Ions for } \\
\text { Identification }\end{array}$ & DP * & $\mathbf{F P} * *$ & $\mathrm{CE}^{\#}$ & CXP \#\# & Cultivar \\
\hline S-methyl-L-cysteine & 2.64 & 136.10 & 118.8 & -31 & -100 & 13 & -15 & M Harnaś * \\
\hline S-allyl-L-cysteine & 3.13 & 162.10 & $145.10 ; 73.10$ & -20 & -200 & 12 & -10 & $\begin{array}{l}\text { M Harnaś * } \\
\text { JN Harnaś * }\end{array}$ \\
\hline S-(trans-1-propenyl)-L-cysteine & 3.47 & 162.40 & 145.04 & -20 & -200 & 8 & -15 & $\begin{array}{l}\text { JL Harnaś * } \\
\text { JL Ornak* }\end{array}$ \\
\hline $\begin{array}{c}(3 R, 5 S)-5 \text {-methyl-1,4-thiazine-3-carboxylic } \\
\text { acid } \\
\text { (cycloalliin) }\end{array}$ & 2.66 & 178.23 & $88.08 ; 91.04$ & -86 & -50 & -15 & -6 & $\begin{array}{l}\text { M Harnaś * } \\
\text { JN Harnaś * } \\
\text { JN Ornak * }\end{array}$ \\
\hline S-allyl-L-cysteine sulfoxide & 3.00 & 178.30 & 88. 4 & -20 & -200 & -15 & -15 & $\begin{array}{l}\text { JN Harnaś * } \\
\text { JL Harnaś * }\end{array}$ \\
\hline
\end{tabular}

${ }^{*}$ DP decluttering potential; ** FP focusing potential; ${ }^{\#}$ CE collision energy; ${ }^{\# \# ~ C X P ~ c o l l i s i o n ~ c e l l ~ e x i t ~ p o t e n t i a l ; ~ M ~ H a r n a s ́ ~ * ~ w h o l e ~ p l a n t s ~ h a r v e s t e d ~ i n ~ M a y ; ~ M ~ O r n a k ~ * ~ w h o l e ~ p l a n t s ~ h a r v e s t e d ~}$ in May; JN Harnas ${ }^{*}$ whole plants in June; JN Ornak * whole plants harvested in June; JL Harnaś ${ }^{*}$ whole plants harvested in July; JL * Ornak whole plants harvested in July. 


\section{Conclusions}

Garlic grown from air bulbils and harvested in May as an immature plant has the best characteristics related to bioactive components. It is worth noting that the bioactive profile of garlic is dependent on harvesting time, and the concentration of bioactive diminishes with plant maturity. Therefore, immature garlic of this type has the best potential to be utilized for its health benefits. However, it is necessary to conduct additional studies focusing on the health-related advantages of garlic cultivated from bulbils.

Author Contributions: Conceptualization and methodology A.K., E.J., and J.Z; formal analysis, A.K., E.J., J.S., R.F., and B.B.; investigation, A.K., E.J., J.S., R.F., and B.B.; data curation, A.K., E.J., J.S., R.F., and B.B.; writing-original draft preparation, A.K. writing-review and editing A.K., E.J., and J.Z. All authors have read and agreed to the published version of the manuscript.

Funding: The study was financed by the Ministry of Science and Higher Education of the Republic of Poland.

Conflicts of Interest: The authors declare no conflict of interest.

\section{References}

1. Santhosha, S.; Jamuna, P.; Prabhavathi, S. Bioactive components of garlic and their physiological role in health maintenance: A review. Food Biosci. 2013, 3, 59-74. [CrossRef]

2. Bhandari, S.R.; Yoon, M.K.; Kwak, J.-H. Contents of phytochemical constituents and antioxidant activity of 19 garlic (Allium sativum L.) parental lines and cultivars. Hortic. Environ. Biotechnol. 2014, 55, $138-147$. [CrossRef]

3. Hornickova, J.; Kubec, R.; Cejpek, K.; Velíšek, J.; Ovesná, J.; Stavělíková, H. Profiles of S-alk(en)ylcysteine sulfoxides in various garlic genotypes. Czech J. Food Sci. 2010, 28, 298-308. [CrossRef]

4. Martins, N.; Petropoulos, S.; Ferreira, I.C. Chemical composition and bioactive compounds of garlic (Allium sativum L.) as affected by pre- and post-harvest conditions: A review. Food Chem. 2016, 211, 41-50. [CrossRef] [PubMed]

5. Arzanlou, M.; Bohlooli, S. Introducing of green garlic plant as a new source of allicin. Food Chem. 2010, 120, 179-183. [CrossRef]

6. Nasim, S.A.; Dhir, B.; Kapoor, R.; Fatima, S.; Mahmooduzzafar; Mujib, A. Alliin obtained from leaf extract of garlic grown under in situ conditions possess higher therapeutic potency as analyzed in alloxan-induced diabetic rats. Pharm. Boil. 2011, 49, 416-421. [CrossRef]

7. Dyduch, J.; Najda, A. Estimation of the biological value of winter garlic leaves from early cultivation on bunch crop part I. Plants grown from clove planting. Electron. J. Pol. Agric. Univ. 2000, 3. Available online: http://www.ejpau.media.pl/volume3/issue2/horticulture/art-05.html (accessed on 1 November 2019).

8. Dyduch, J.; Najda, A. Estimation of the biological value of winter garlic leaves from early cultivation on bunch crop. Part II. Plants grown from planting air bulbs. Electron. J. Pol. Agric. Univ. 2001, 4. Available online: http://www.ejpau.media.pl/volume4/issue2/horticulture/art-04.html (accessed on 1 November 2019).

9. Chen, S.; Shen, X.; Cheng, S.; Li, P.; Du, J.; Chang, Y.; Meng, H. Evaluation of Garlic Cultivars for Polyphenolic Content and Antioxidant Properties. PLoS ONE 2013, 8. [CrossRef]

10. Kim, H.-H.; Lee, J.-K.; Yoon, J.-W.; Ji, J.-J.; Nam, S.-S.; Hwang, H.-S.; Cho, E.-G.; Engelmann, F. Cryopreservation of garlic bulbil primordia by the droplet-vitrification procedure. CryoLetterrs 2006, 27, 143-153.

11. Vieira, R.L.; da Silva, A.L.; Zaffari, G.R.; Steinmacher, D.A.; Freitas Fraga, H.P.; Guerra, M.P. Efficient elimination of virus complex from garlic (Allium sativum L.) by cryotherapy of shoot tips. Acta Physiol. Plant. 2015, 37, 1733-1746. [CrossRef]

12. Kallel, F.; Driss, D.; Chaari, F.; Belghith, L.; Bouaziz, F.; Ghorbel, R.; Chaabouni, S.E. Garlic (Allium sativum L.) husk waste as a potential source of phenolic compounds: Influence of extracting solvents on its antimicrobial and antioxidant properties. Ind. Crop. Prod. 2014, 62, 34-41. [CrossRef]

13. Piatkowska, E.; Kopeć, A.; Leszczyńska, T. Basic chemical composition, content of micro- and macroelements and antio xidant activity of different varieties of garlic's leaves polish origin. Food Sci. Technol. Qual. 2015, 1, 181-192. 
14. Dziadek, K.; Kopeć, A.; Piątkowska, E.; Leszczyńska, T.; Pisulewska, E.; Witkowicz, R.; Bystrowska, B.; Francik, R. Identification of polyphenolic compounds and determination of antioxidant activity in extracts and infusions of buckwheat leaves. Eur. Food Res. Technol. 2018, 244, 333-343. [CrossRef]

15. AOAC. International: Official Methods of Analysis, 17th ed.; AOAC International: Gaithesburg, MD, USA, 2006.

16. Metzger, L.E.; Nielsen, S.S. Nutrition labeling in food analysis. In Food Analysis, 5th ed.; Nielsen, S.S., Ed.; Springer: Cham, Switzerland, 2017; pp. 35-43.

17. Food Products-Determination of Vitamin C PN-A-04019:1998; Polish Committee for Standardization: Warsaw, Poland, 1998.

18. Swain, T.; Hillis, W.E. The phenolic constituents ofPrunus domestica. I.-The quantitative analysis of phenolic constituents. J. Sci. Food Agric. 1959, 10, 63-68. [CrossRef]

19. Re, R.; Pellegrini, N.; Proteggente, A.; Pannala, A.; Yang, M.; Rice-Evans, C. Antioxidant activity applying an improved ABTS radical cation decolorization assay. Free. Radic. Boil. Med. 1999, 26, 1231-1237. [CrossRef]

20. Benzie, I.F.; Strain, J. The Ferric Reducing Ability of Plasma (FRAP) as a Measure of "Antioxidant Power": The FRAP Assay. Anal. Biochem. 1996, 239, 70-76. [CrossRef]

21. Miliauskas, G.; Venskutonis, P.; Van Beek, T. Screening of radical scavenging activity of some medicinal and aromatic plant extracts. Food Chem. 2004, 85, 231-237. [CrossRef]

22. Lichtenthaler, H.K.; Wellburn, A.R. Determinations of total carotenoids and chlorophylls a and b of leaf extracts in different solvents. Biochem. Soc. Trans. 1983, 11, 591-592. [CrossRef]

23. Guri, A. Variation in Glutathione and Ascorbic acid Content Among Selected Cultivars of Phaseolus vulgaris PRIOR TO AND AFTER EXPOSURE TO OZONE. Can. J. Plant Sci. 1983, 63, 733-737. [CrossRef]

24. Wallock-Richards, D.; Doherty, C.J.; Doherty, L.; Clarke, D.J.; Place, M.; Govan, J.R.W.; Campopiano, M.J. Garlic Revisited: Antimicrobial Activity of Allicin-Containing Garlic Extracts against Burkholderia cepacia Complex. PLoS ONE 2014, 9. [CrossRef] [PubMed]

25. Van Hung, P.; Morita, N. Distribution of phenolic compounds in the graded flours milled from whole buckwheat grains and their antioxidant capacities. Food Chem. 2008, 109, 325-331. [CrossRef] [PubMed]

26. Verardo, V.; Arráez-Román, D.; Carretero, A.S.; Marconi, E.; Fernández-Gutiérrez, A.; Caboni, M.F. Identification of buckwheat phenolic compounds by reverse phase high performance liquid chromatography-electrospray ionization-time of flight-mass spectrometry (RP-HPLC-ESI-TOF-MS). J. Cereal Sci. 2010, 52, 170-176. [CrossRef]

27. Azzini, E.; Durazzo, A.; Foddai, M.S.; Temperini, O.; Venneria, E.; Valentini, S.; Maiani, G. Phytochemicals Content in Italian Garlic Bulb (Allium sativum L.) Varieties. J. Food Res. 2014, 3, 26-32. [CrossRef]

28. Gorinstein, S.; Leontowicz, H.; Leontowicz, M.; Namieśnik, J.; Najman, K.; Drzewiecki, J.; Cvikrová, M.; Martincová, O.; Katrich, E.; Trakhtenberg, S. Comparison of the Main Bioactive Compounds and Antioxidant Activities in Garlic and White and Red Onions after Treatment Protocols. J. Agric. Food Chem. 2008, 56, 4418-4426. [CrossRef] [PubMed]

29. Jęrrszczyk, E.; Kopeć, A.; Szymanowski, M.; Skowera, B. Proximate chemical composition and concentrations of selected bioactive compounds in the leaves, stems and bulbs of wild garlic (Allium ursinum L.). Fresenius Environ. Bull. 2019, 28, 4778-4785.

30. Beato, V.M.; Orgaz, F.; Mansilla, F.; Montaño, A. Changes in Phenolic Compounds in Garlic (Allium sativum L.) Owing to the Cultivar and Location of Growth. Plant Foods Hum. Nutr. 2011, 66, 218-223. [CrossRef]

31. Alarcón-Flores, M.I.; Romero-González, R.; Vidal, J.L.M.; Frenich, A.G. Determination of Phenolic Compounds in Artichoke, Garlic and Spinach by Ultra-High-Performance Liquid Chromatography Coupled to Tandem Mass Spectrometry. Food Anal. Methods 2014, 7, 2095-2106. [CrossRef]

32. Mercy, O.A.; Simeon, O.O.; Saheed, A.; Ayokunle, O.; Temitope, A.E. Analysis of phenolic compounds, phytosterols, lignans and stilbenoids in garlic and ginger oil by gas chromatography. J. Food Chem. Nutr. 2014, 2, 53-60.

33. Zeng, Y.; Li, Y.; Yang, J.; Pu, X.; Du, J.; Yang, X.; Yang, T.; Yang, S. Therapeutic Role of Functional Components in Alliums for Preventive Chronic Disease in Human Being. Evid.-Based Complement. Altern. Med. 2017, 2017, 1-13. [CrossRef] 
34. Bloem, E.; Haneklaus, S.; Schnug, E. Influence of Fertilizer Practices on S-Containing Metabolites in Garlic (Allium sativum L.) under Field Conditions. J. Agric. Food Chem. 2010, 58, 10690-10696. [CrossRef] [PubMed]

35. Beato, V.M.; Sánchez, A.H.; De Castro, A.; Montaño, A. Effect of Processing and Storage Time on the Contents of Organosulfur Compounds in Pickled Blanched Garlic. J. Agric. Food Chem. 2012, 60, 3485-3491. [CrossRef] [PubMed] 